\title{
Penginderaan Jauh Pemrosesan Data Satelit Landsat 8 Untuk Deteksi Genangan
}

\author{
Tania Maria Octarina, I Dewa Nyoman Nurweda Putra, Ni Kadek Ayu Wirdiani \\ Jurusan Teknologi Informasi, Fakultas Teknik, Universitas Udayana \\ e-mail: mariataniaa96@gmail.com, nurweda14@unud.ac.id, ayuwirdiani@unud.ac.id
}

\begin{abstract}
Abstrak
DKI Jakarta merupakan daerah yang terkenal dengan bencana banjir pada musim hujan setiap tahun. Salah satu informasi mendasar yang dibutuhkan terkait bencana banjir adalah daerah tergenang banjir. Informasi genangan banjir digunakan untuk melakukan pemetaan dan perhitungan luas genangan, sehingga dapat diketahui daerah yang memiliki potensi banjir. Perhitungan informasi genangan banjir menjadi ide dasar dibentuknya penginderaan jauh pemrosesan data satelit Landsat 8 untuk deteksi genangan. Landsat 8 dimanfaatkan sebagai parameter utama dalam melakukan identifikasi genangan pada penelitian ini. Metode GSWIR (Green-Short Wave Infrared) diaplikasikan pada citra Landsat 8 menggunakan Band 3 (Green) dan Band 6 (SWIR). Metode GSWIR merupakan filter edge detection yang digunakan untuk memisahkan antara air dan non air. Hasil perhitungan metode GSWIR menunjukkan obyek permukaan mempunyai respon spektral dan luas yang bervariasi saat banjir (tergenang air) dan tidak banjir (tidak tergenang air). Metode GSWIR yang diaplikasikan membuktikan metode ini dapat digunakan untuk mendeteksi genangan dengan memisahkan antara air (genangan) dan non air (tidak tergenang air) dikarenakan Band Green memiliki kegunaan untuk memperbesar nilai reflektan dari air, dan badan air memiliki daya serap lebih kuat pada band SWIR.
\end{abstract}

Kata kunci: DKI Jakarta, Genangan, Landsat 8 , GSWIR.

\begin{abstract}
DKI Jakarta is an area that familiar for floods that occur every year during the rainy season. One of the basic information needed is a flooded area. Flood inundation information is used to carry out mapping and calculation of inundation area, the areas with potential flooding can be identified. The selection of Landsat 8 serves as the main parameter in identifying inundation. The GSWIR method (Green-Short Wave Infrared) uses Band 3 and Band 6 imagery to do processing in the system. The results of the calculation method is surface objects have various spectral response and wide when flooded (flooded) and does not flood (dry / not flooded). The results of the wide comparison of GSWIR are closer to the real extent. The GSWIR method has proven to be detailed in detecting inundation and can be used to separate land and water, because the Green Band has a function to increase the reflectance value of water and the water body has a stronger absorption capacity in the SWIR band.
\end{abstract}

Kata kunci: DKI Jakarta, Genangan, Landsat 8 , GSWIR.

\section{Pendahuluan}

Banjir adalah salah satu kejadian ketika daratan digenangi oleh aliran air yang berlebih. Bencana banjir hampir terjadi di setiap tahun, terutama pada musim hujan, misalnya Jakarta banjir sudah terjadi sejak 1959 [1]. Daerah tergenang banjir dibutuhkan sebagai informasi mendasar pada penelitian ini.

Daerah tergenang banjir digunakan untuk melakukan proses pemetaan dan perhitungan luas genangan, sehingga dapat diketahui daerah yang memiliki potensi banjir pada saat musim hujan. Penelitian daerah tergenang banjir didapatkan melalui satelit Landsat 8 . Satelit Landsat 8 menghasilkan citra keadaan permukaan bumi secara periodik.

Penelitian terkait Landsat 8 OLI/TIRS, Komposit Citra ataupun Metode GSWIR pernah dilakukan sebelumnya. Pemanfaatan terkait penggunaan citra [2] menggunakan data penginderaan jauh Landsat 8 OLI/TIRS. Penelitian oleh Sanjaya Putra [3] menggunakan metode NDVI dilakukan pada hutan mangrove Ngurah Rai. NDVI digunakan untuk mengidentifikasi vegetasi. Proses identifikasi tutupan mangrove dilakukan dengan klasifikasi nilai NDVI Treshold 
menjadi beberapa tingkatan nilai. Proses NDVI menggunakan tiga band yang di-input yaitu Near Infrared, Red dan Blue.

Penelitian terkait komposit RGB menggunakan data Digital Elevation Model (DEM) dan Landsat 7 sebagai data pendukung diterapkan pada [4] [5]. Data Landsat 7 diproses menggunakan Band 1, 2 dan 3 untuk mendapatkan true color dan Band 1, Band 4 dan Band 5 untuk mendapatkan citra termal dari wilayah DKI Jakarta. Hasil segementasi DEM dan citra komposit dari Landsat 7 , kedua data diregistrasi agar posisi koordinat bersesuaian sehingga memudahkan proses lebih lanjut. Data yang teregistrasi kemudian di-cropping untuk menentukan area of interest (daerah pengamatan).

Penelitian sebelumnya yang membahas mengenai banjir [6] menggunakan citra satelit bersumber dari GSMaP. GSMaP dipergunakan untuk mengambil data curah hujan setiap jam di seluruh dunia. Aplikasi ini menggunakan metode statistika deskriptif untuk memperoleh keputusan bahwa banjir terjadi akibat curah hujan yang tinggi atau disebabkan banjir kiriman. Hasil pengujian aplikasi yaitu pola hujan di Jakarta dan Bogor dalam bentuk grafik pola hujan untuk menentukan penyebab banjir di Jakarta. Penelitian oleh Suwarsono [7] mengidentifikasi daerah tergenang menggunakan metode NDWI dari data Landsat TM / ETM+ pada dataran rendah Pulau Jawa. Analisis parameter NDWI yang digunakan merupakan NDWI dari Gao (1996), NDWI dari McFeeters (1996), MNDWI dari Xu (2006) dan NWI dari Yang dan kawan - kawan (2011) untuk mendeteksi daerah tergenang. Penelitian terkait penggunaan band citra pada [8] melakukan perbandingan metode NDWI dan MNDWI. Metode NDWI menggunakan band Green dan band NIR, sedangkan Metode MNDWI menggunakan band Green dan band SWIR. Badan air memiliki daya serap lebih kuat pada band SWIR di bandingkan dengan band NIR. Hasil perbandingan dari NDWI dan MNDWI menunjukan kedua metode dapat meningkatkan perbedaan air dan non-air. Percobaan yang terletak di Pantai Venesia menunjukan bahwa MNDWI lebih efisien untuk meningkatkan badan air dibandingan dengan NDWI. Metode NDWI pada badan air menghasilkan garis air yang tidak begitu terlihat dan tepi yang bergerigi dikarenakan resolusi spasial yang relaif kasar. Metode MNDWI menampilkan lebih banyak detail spasial dari badan air terutama garis batas perairan terlihat lebih jelas dan lebih hasil, hal ini dikarenakan band SWIR yang digunakan dalam MNDWI. Penelitian dengan judul [9] menggunakan metode NDWI (Normalize Difference Water Index)), metode water index yang dapat disebut RSWIR (Red and Short Wave Infra-Red) dan metode water index GSWIR (Green and Short Wave Infra-Red) untuk menggambarkan dan mapping permukaan air menggukanan citra MODIS (Terra) tahun 2012 di Pakistan saat banjir dengan menggunakan data banding dari Landat TM.

Mengacu pada penelitian sebelumnya, penelitian yang dikembangkan menggunakan data satelit Landsat 8 dan metode GSWIR yang diterapkan untuk identifikasi objek berbeda yaitu genangan air. Landsat 8 memiliki resolusi spasial 30 meter yang ideal untuk melakukan deteksi, pengukuran, dan menganalisis perubahan-perubahan objek-objek pada permukaan bumi pada level yang rinci [10]. Satelit Landsat 8 diterapkan karena mampu menghasilkan citra yang digunakan sebagai pemrosesan data deteksi genangan banjir. Metode Green-Shortwave Infrared merupakan filter edge detection, yang digunakan untuk memisahkan antara daratan dan perairan. Pemilihan metode GSWIR dikarenakan dari hasil penelitian sebelumnya, metode GSWIR memiliki potensi yang baik dalam melakukan pengolahan citra mengenai air. Band Green dan band SWIR dinyatakan mampu melakukan deteksi genangan dengan baik pada penelitian [8]. Band Green mampu memperbesar nilai reflektan air dan band SWIR memiliki daya serap yang baik pada badan air. Genangan banjir digunakan sebagai data analisis untuk pemrosesan citra Landsat 8 . Analisis menggunaan dua genangan yaitu saat banjir dan tidak banjir.

\section{Metodologi Penelitian}

Metodelogi penelitian membahas mengenai tahapan penelitian dan gambaran umum dari sistem penginderaan jauh deteksi genangan.

\subsection{Gambaran Umum Sistem}

Perancangan sistem merupakan tahap mentransformasikan data dan arsitektur program yang diimplementasikan pada tahapan pembuatan sistem. 


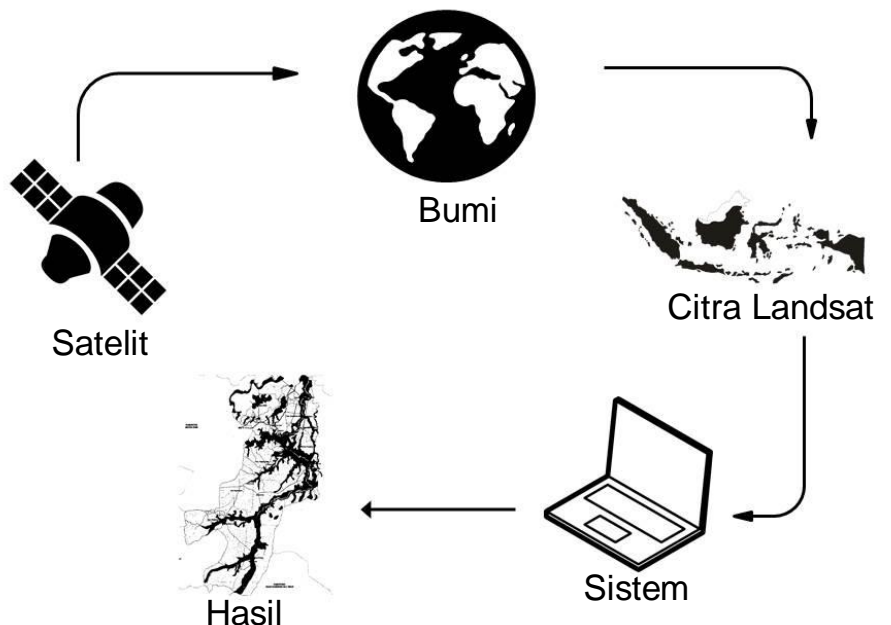

Gambar 1. Gambaran Umum Sistem

Gambar 1 menjelaskan data citra Landsat 8 didapat melalui satelit USGS (U.S Geological Survey). Satelit USGS berotasi selama 2 minggu sekali untuk mengitari seluruh bumi. Citra dari satelit USGS dapat diperoleh dengan men-download-nya dari web yang disediakan oleh USGS. Langkah sebelum melakukan download, terlebih dahulu ditentukan daerah yang akan diambil data citranya. Landsat 8 berfungsi untuk menampilkan citra berupa permukaan bumi atau suatu daerah. Pengambilan data citra Landsat 8 digunakan untuk melakukan deteksi daerah genangan banjir. Data citra yang didapatkan akan diolah dalam sistem sehingga memperoleh hasil berupa citra digital yang menggambarkan luas daerah tergenang banjir pada daerah DKI Jakarta.

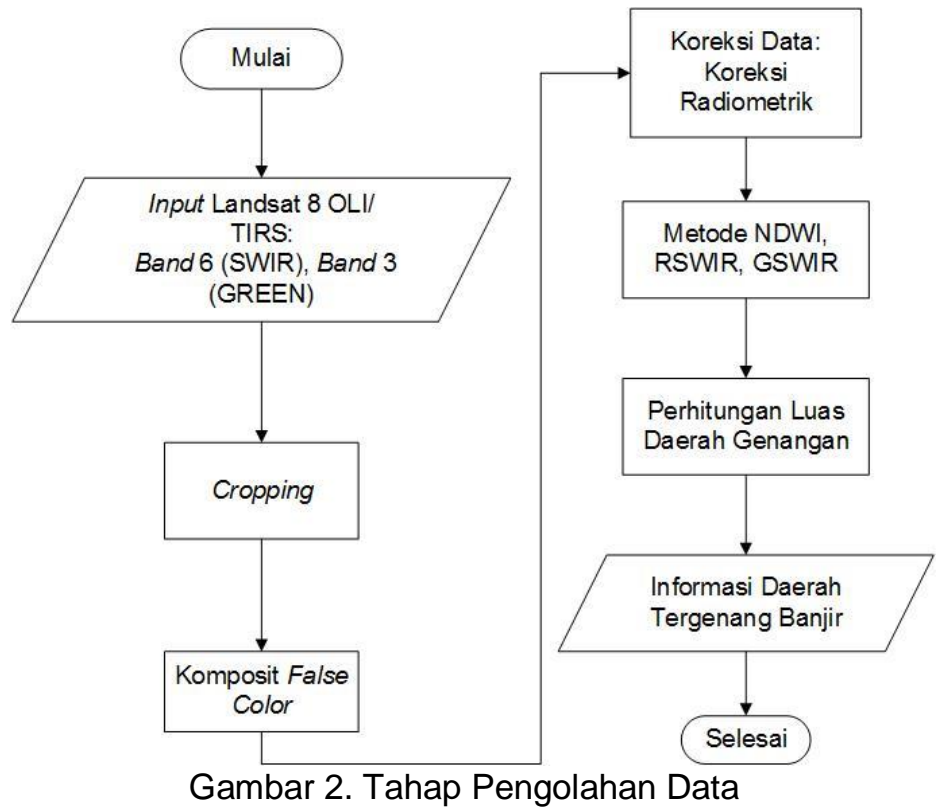

Hal pertama dilakukan untuk mendapatkan peta daearah genangan banjir yaitu melakukan input citra seperti Gambar 2. Band yang di input merupakan Band 6 (Short Wave Infrared) dan Band 3 (Green) dari Landsat 8. Band 6 disebut SWIR (Short Wave Infrared) digunakan untuk memisahkan kadar air tanah dan vegetasi; menembus awan tipis. Band 3 disebut Green memiliki fungsi memperjelas puncak vegetasi untuk menilai kekuatan vegetasi. Band 6 dan Band 3 akan dilakukan koreksi radiometrik yang ditujukan untuk memperbaiki nilai piksel sehingga sesuai dengan seharusnya, dilakukan dengan mempertimbangkan faktor gangguan atmosfer sebagai sumber kesalahan utama.

Aplikasi melakukan proses pengolahan menggunakan citra satelit Landsat 8 yang sebelumnya sudah di crop. Proses selanjutnya, citra diolah dengan menggunakan metode 
GSWIR (Green and Short Wave Infra-red). Hasil data citra Landsat 8 yang telah diolah akan menampilkan citra area yang berupa air dan non air serta, sehingga mendapatkan hasil akhir berupa daerah genangan banjir pada daerah DKI Jakarta dengan luasan genangan dari metode GSWIR.

\subsection{Pemilihan Citra}

Tahap awal proses pengolahan citra Landsat untuk interpretasi objek genangan banjir pada daerah DKI Jakarta dilakukan dengan memilih Band 3 (Green) dan Band 6 (Short Wave Infrared). Keempat band dari Landsat 8 memiliki karakteristik awal warna citra yang sama yaitu grayscale.

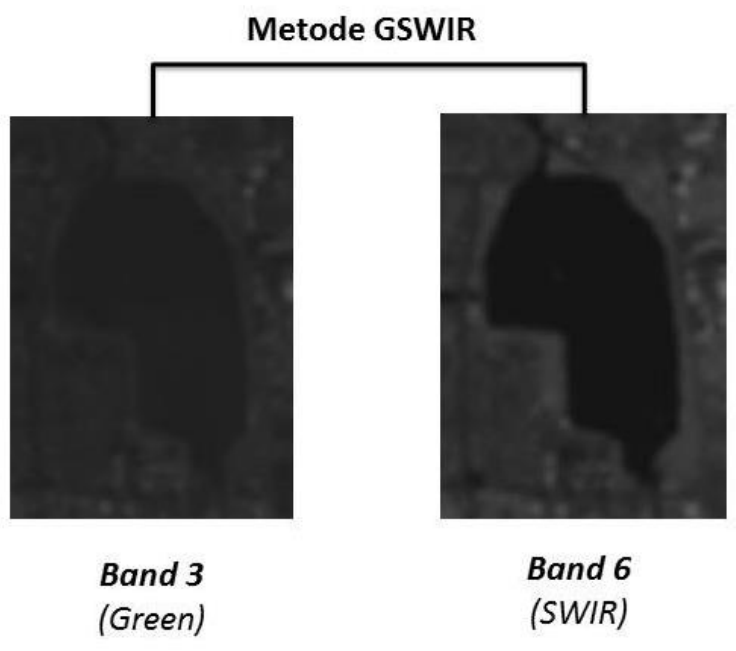

Gambar 3. Pemilihan Citra

Gambar 3 menunjukan kombinasi dari kedua band tersebut digunakan untuk tahap pengolahan yaitu proses komposit dan proses metode GSWIR. Komposit false color dilakukan agar memudahkan peneliti dalam melakukan interpretasi terhadap suatu objek dalam citra. Objek yang diteliti dapat dengan mudah dikenali berdasarkan dominasi warna yang dimiliki citra kombinasi tersebut terutama pada objek citra Genangan Banjir DKI Jakarta. Proses komposit false color dilakukan dengan menggunakan band 3, band 5 dan band 6 untuk proses GSWIR Proses GSWIR menggunakan band 3 dan band 6 dan akan dilakukan perhitungan luas menggunakan nilai indeks atau thresholding.

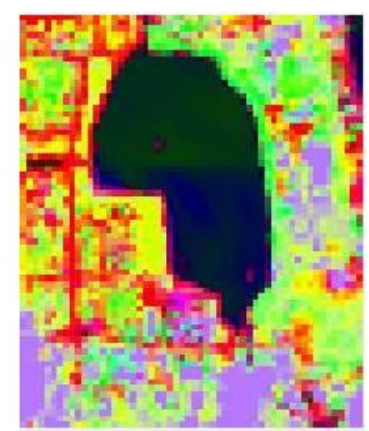

Saat Banjir

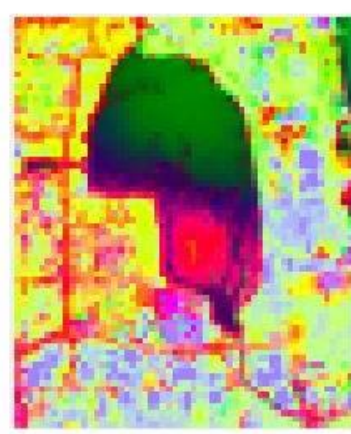

Tidak Banjir

Gambar 4. Hasil Komposit False Color

Warna yang dihasilkan dari Gambar 4, bukan merupakan warna yang sebenarnya, melainkan warna false color yang berfungsi memudahkan dalam melakukan interpretasi terhadap suatu objek berdasarkan dominasi warna yang ditampilkan. 


\subsection{Perhitungan Luas}

Perhitungan luas genangan dengan GSWIR dilakukan dengan menjumlahkan nilai piksel biner yang telah didapatkan. Nilai GSWIR berkisaran -1 dan +1 , nilai 0 sampai dengan +1 berarti objek teridentifikasi sebagai badan air dan -1 sampai dengan 0 berarti objek teridentifikasi sebagai non-badan air. Hasil dari penjumlahan setiap piksel di proses dengan mengalikan jumlah nilai piksel yang ada dengan standar resolusi spasial band citra yang digunakan dalam proses pengolahan. Nilai resolusi spasial untuk citra band 5 , band 6 dan band 3 yaitu $30 \mathrm{~m} \times 30 \mathrm{~m}$ atau $900 \mathrm{~m}^{2}$, sehingga semua nilai piksel biner dikalikan dengan resolusi spasial band 5 , band 6 dan band 3 yaitu $900 \mathrm{~m}^{2}$.

\begin{tabular}{|c|c|c|c|c|}
\hline \multicolumn{5}{|c|}{ NDWI/ RSWIR/ GSWIR } \\
\hline-0.21 & -0.22 & -0.13 & -0.23 & -0.11 \\
\hline-0.14 & 0.32 & 0.40 & 0.23 & 0.42 \\
\hline 0.35 & 0.43 & 0.47 & -0.15 & -0.20 \\
\hline-0.11 & 0.34 & 0.33 & 0.25 & -0.16 \\
\hline-0.22 & 0.25 & 0.36 & -0.19 & -0.24 \\
\hline
\end{tabular}

\begin{tabular}{|c|c|c|c|c|}
\hline \multicolumn{5}{|c|}{ NDWI/ RSWIR/ GSWIR } \\
\hline 0 & 0 & 0 & 0 & 0 \\
\hline 0 & 1 & 1 & 1 & 1 \\
\hline 1 & 1 & 1 & 0 & 0 \\
\hline 0 & 1 & 1 & 1 & 0 \\
\hline 0 & 1 & 1 & 0 & 0 \\
\hline
\end{tabular}

Gambar 4. Perhitungan Luas

Nilai Piksel GSWIR:

$$
\begin{aligned}
& =(0+0+0+0+0)+(0+1+1+1+1)+(1+1+1+0+0)+(0+1+1+1+0)+(0+1+1+0+0) \\
& =0+4+3+3+2 \\
& =12
\end{aligned}
$$

Nilai Total Luas Genangan GSWIR:

$=$ Nilai Piksel Citra $\times$ Resolusi Spasial Landsat $8\left(\mathrm{~m}^{2}\right)$

$$
\begin{aligned}
& =12 \times 900\left(\mathrm{~m}^{2}\right) \\
& =10.800 \mathrm{~m}^{2}
\end{aligned}
$$

Proses perhitungan luas genangan Gambar 4. menggunakan ukuran matriks $5 \times 5$. Nilai suatu badan air berkisar 0 sampai dengan +1 , selain rentang dari nilai piksel tersebut nilai dijadikan 0 , karena nilai GSWIR berkisaran +1 dan 0 . Nilai biner 1 yang berada dalam matriks ukuran $5 \times 5$ dikalikan dengan resolusi spasial Landsat $\left(\mathrm{m}^{2}\right)$, sehingga menghasilkan luas total vegetasi yaitu $10.800 \mathrm{~m}^{2}$.

\section{Kajian Pustaka}

Kajian pustaka sebagai penunjang pembangunan sistem penginderaan jauh untuk deteksi Genangan menggunakan Landsat 8 sebagai berikut.

\subsection{Sistem Penginderaan Jauh}

Sistem fotografik dan non fotografik merupakan dua jenis sistem penginderaan jauh. Kedua sistem memiliki kelebihan masing-masing, kelebihan sistem fotografik yaitu tidak mahal, sederhana, dan kualitasnya baik. Kelebihan sistem elektronik memiliki kemampuan yang lebih jelas dalam membedakan objek dan lebih cepat melakukan proses analisi. Sistem penginderaan jauh juga dibedakan berdasarkan tenaga yang digunakan yaitu tenaga pancaran dan tenaga pantulan. Sistem penginderaan dirgantara (airbone sistem), dan antariksa (spaceborne sistem) merupakan sistem penginderaan jauh berdasarkan wahana yang digunakan [11].

\subsection{Landsat}

Citra Landsat merupakan visualisasi permukaan bumi yang diambil dari luar angkasa dengan ketinggian kurang lebih $818 \mathrm{~km}$ dari permukaan bumi, memiliki skala $1: 250.000$. Perekaman citra landsat masing - masing mempunyai cakupan area $185 \mathrm{~km} \times 185 \mathrm{~km}$ sehingga aspek dari objek tertentu dapat diidentifikasi tanpa perlu menjelajah seluruh daerah yang disurvei atau yang diteliti [12].

\subsubsection{Landsat 8}

Penginderaan Jauh Pemrosesan Data Satelit Landsat 8 untuk Deteksi Genangan 
Landsat 8 atau Landsat Data Continuity Mission (LDCM) merupakan satelit generasi terbaru dari program Landsat. USGS dan NASA serta NASA Goddard Space Flight Center bekerja sama membuat projek satelit Landsat 8 yang diluncurkan pada 11 Februari 2013 di Pangkalan Angkatan Udara Vandeberg, California - Amerika Serikat. Satelit Landsat 8 dirancang mempunyai durasi misi selama 5 - 10 tahun, memiliki dua sensor yang merupakan hasil pengembangan dari sensor yang terdapat pada satelit-satelit program Landsat sebelumnya. Sensor dalam Landsat 8 yaitu Sensor Operational Land Manager (OLI) yang terdiri dari 9 band serta Sensor Thermal InfraRed Sensors (TIRS) yang terdiri dari 2 band [10].

\subsection{Koreksi Atmosfer}

Koreksi ToA (Top of Atmosphere) merupakan koreksi citra yang dilakukan untuk menghilangakan kerusakan radiometrik disebabkan oleh posisi matahari. Posisi matahari terhadap bumi bergantung pada waktu perekaman dan lokasi obyek yang direkam. Cara koreksi ToA dilakukan dengan mengubah nilai digital number ke nilai reflektansi. Tujuan Koreksi ToA adalah mengevaluasi karakteristik reflektansi dari citra Landsat-8 untuk obyek vegetasi (hutan dan sawah), lahan terbuka (lahan gundul dan pemukiman) dan air (laut, danau dan sungai [13].

Koreksi ToA pada data Landsat 8 meliputi ToA Reflektansi dan koreksi matahari. Koreksi ToA Reflektansi dilakukan dengan mengkonversi nilai DN ke nilai reflektansi.

$$
\mathrm{P} \lambda^{\prime}=\mathrm{M} \rho \mathrm{Qcal}+\mathrm{A} \rho
$$

$\rho \lambda^{\prime}=$ Top-of-Atmosphere Planetary Spectral Reflectance, without correction for solar angle. (Unitless)

$\mathrm{M} \rho=$ Reflectance multiplicative scaling factor for the band (REFLECTANCEW_MULT_BAND_n from the metadata).

$\mathrm{A} \rho=$ Reflectance additive scaling factor for the band (REFLECTANCE_ADD_BAND_N from the metadata).

Qcal = Level 1 pixel value in DN

\subsection{Metode NDWI, RSWIR dan GSWIR}

NDWI adalah suatu algoritma yang digunakan untuk deteksi badan air. Badan air memiliki kapasitas untuk menyerap secara kuat panjang gelombang sinar tampak dan infra merah. Nilai NDWI lebih besar dari nol maka dikatakan mewakili permukaan badan air, dan jika nilai NDWI lebih kecil atau sama maka dikatakan sebagai permukaan bukan air.[10]

$$
N D W I=\frac{\rho 3(\text { GREEN })-\rho 5(N I R)}{\rho 3(\text { GREEN) }+\rho 5(N I R)}
$$

[10] memperkenalkan NDWI dengan menggunakan saluran merah (red) dan saluran Short Wave Infrared (SWIR) pada Landsat.

$$
R S W I R=\frac{\rho 4(R E D)-\rho 6(S W I R)}{\rho 4(R E D)+\rho 6(S W I R)}
$$

[10] menggunakan data spectral untuk mensimulasikan data satelit dan menghitung NDWI dalam berbagai bentuk, kemudian menyimpulkan NDWI yang telah dihitung menggunakan saluran hijau (green) dan Short Wave Infrared (SWIR).

$$
G S W I R=\frac{\rho 3(\text { GREEN })-\rho 6(\text { SWIR })}{\rho 3(\text { GREEN })+\rho 6(\text { SWIR })}
$$

\section{Hasil dan Pembahasan}

Hasil dan pembahasan terhadap uji coba sistem penginderaan jauh untuk deteksi Genangan menggunakan Landsat 8. 


\subsection{Uji Coba Metode GSWIR}

Proses komputasi pada metode GSWIR dalam mendeteksi genangan banjir menggunakan nilai indeks kebasahan. Nilai indeks kebasahan memiliki beberapa tingkat yaitu 1.0 sampai dengan 0 berarti non badan air atau tidak memiliki nilai kebasahan, 0 sampai dengan 0.33 memiliki tingkat kebasahan sedang dan sudah termasuk badan air, 0.33 sampai dengan 1 memiliki tingkat kebasahan yang tinggi.

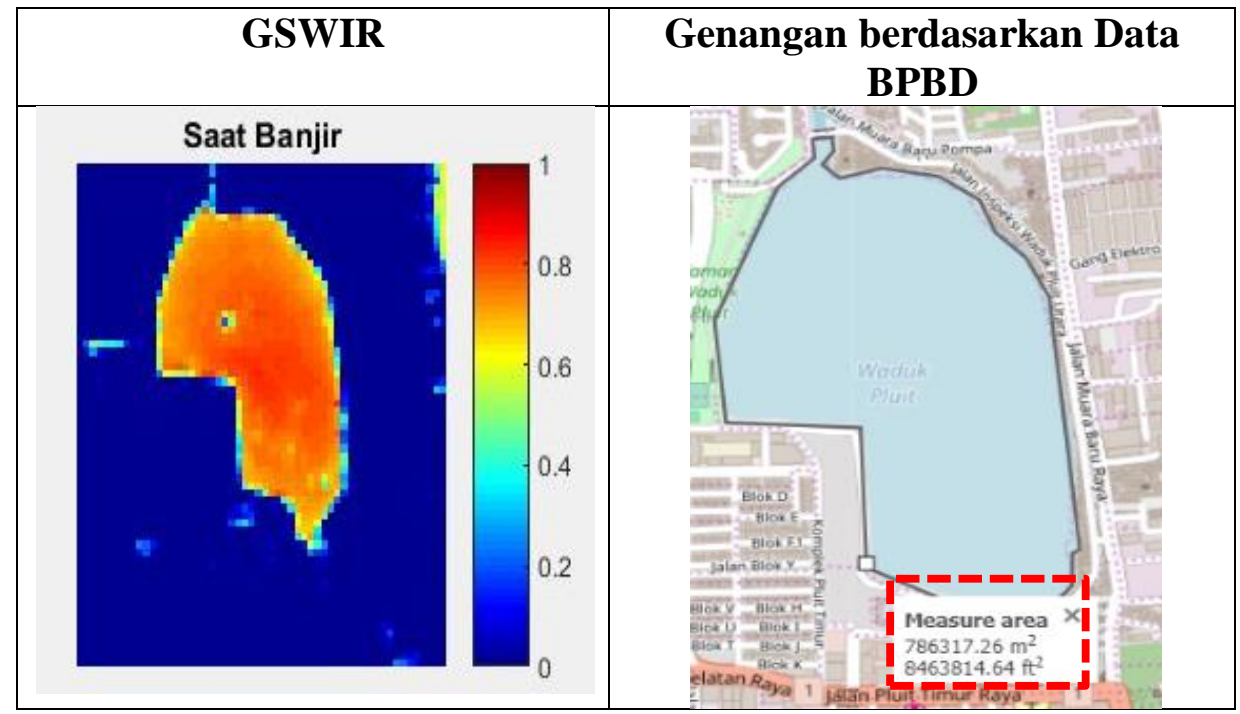

Gambar 5. Metode GSWIR

Genangan saat banjir pada Gambar 5 memiliki nilai indeks sekitar 0.7 sampai 0.8 , sehingga genangan termasuk dalam kategori nilai indeks kebasahan tinggi. Sekeliling genangan bernilai indeks -0.3 sampai dengan 0 yang berarti non badan air dan tidak memiliki nilai kebasahan. Bagian kanan merupakan citra dari open street map, yang didapatkan dari website resmi milik BPBD (Badan Penanggulangan Bencana Daerah) Provinsi DKI Jakarta. Citra open street map diambil saat keadaan banjir pada Bulan Febuari tahun 2016. Peta genangan banjir pada open street map BPDD Provinsi DKI Jakarta Bulan Febuari 2016 memiliki luas genangan $786.317,26 \mathrm{~m}^{2}$

\subsection{Hasil Metode}

Hasil yang di dapat dari proses komputasi penggunaan metode GSWIR yaitu penggunaan metode GSWIR dalam menghitung luas genangan banjir menjadi efisien, karena proses perhitungan dengan menggunakan metode GSWIR menggunakan band 3 (Green) dan band 6 (Short Wave Infrared). Band 3 ini sudah terlihat tepian antara daratan dan lautan yang cukup jelas. Band 3 disebut dengan Green yang dapat juga digunakan untuk memberikan informasi mengenai vegetasi dan non vegetasi pada wilayah tersebut dan menambah nilai reflektan pada air, sehingga visualisasi genangan (air) dapat diperjelas. Band 6 disebut dengan Short Wavelength Infrared (SWIR) digunakan untuk mengetahui perbedaan tanah tidak berbatas dengan objek lain. Band ini sesuai dengan kajian kandungan air tanah, air pada tanamantanaman, formasi batu-batuan dan geologi pada umumnya.

Tabel 1. Hasil Perbandingan Luas Genangan Banjir

\begin{tabular}{|c|c|c|c|c|c|c|}
\hline \multirow{2}{*}{ No. } & \multirow{2}{*}{ Metode } & \multicolumn{5}{|c|}{ Perbandingan Luas } \\
\cline { 3 - 7 } & & $\begin{array}{c}\text { Saat Banjir } \\
\left(\mathrm{m}^{2}\right)\end{array}$ & $\begin{array}{c}\text { Tidak Banjir } \\
\left(\mathrm{m}^{2}\right)\end{array}$ & $\begin{array}{c}\text { Selisih Nilai } \\
\left(\mathrm{m}^{2}\right)\end{array}$ & $\begin{array}{c}\text { Selisih dengan } \\
\text { Data BPBD } \\
\left(\mathrm{m}^{2}\right)\end{array}$ & $\begin{array}{c}\text { Nilai } \\
\text { Error }(\%)\end{array}$ \\
\hline 1 & GSWIR & $751.500,00$ & $636.300,00$ & $115.200,00$ & $34.817,26$ & 4 \\
\hline
\end{tabular}

Tabel 1 memperlihatkan perbandingan nilai-nilai luas yang dimiliki dari metode GSWIR. Kolom saat banjir merupakan luas daerah saat banjir. Kolom tidak banjir berisikan luas daerah 
yang dihasilkan dalam sistem ketika tidak banjir. Kolom selisih nilai merupakan nilai selisih luas genangan antara saat banjir dan tidak banjir. Kolom selisih dengan data BPBD yaitu selisih nilai dari data BPBD yaitu $786.317,26 \mathrm{~m}^{2}$ dengan data luas saat banjir dalam sistem.

Penelitian oleh Yun Du [8] menyatakan bahwa metode yang menggunakan band Green dan band SWIR lebih banyak mendeteksi daerah genangan (air) dibandingkan dengan metode yang menggunakan band Green dan band NIR, dikarenakan Badan air memiliki daya serap lebih kuat pada band SWIR di bandingkan dengan band NIR. Band Red merupakan band yang berfungsi untuk mendeteksi vegetasi dan melakukan klasifikasi dalam vegetasi [14]. Berdasarkan hasil penelitian Penginderaan Jauh Pemrosesan Data Satelit Landsat 8 untuk Deteksi Genangan metode GSWIR mendekati nilai asli dikarenakan band Green memiliki kegunaan untuk memperbesar nilai reflektan dari air. Band SWIR berfungsi untuk membedakan tanah basah dari bumi kering, dan geologi seperti batuan dan tanah yang terlihat mirip di band lain, sering memiliki kontras yang kuat di SWIR

\section{Kesimpulan}

Luasnya area tergenang yang disebabkan oleh banjir di daerah dataran dapat diidentifikasi dan dibedakan antara genangan dan daratan (kering) berdasarkan GSWIR variabel. Data Landsat 8 dapat membantu deteksi area tergenang dipengaruhi pada indeks yang digunakan. Hasil menunjukkan bahwa metode GSWIR secara visual, mampu memperjelas batas antara air (genangan) dan non air, hal ini karena band Green berfungi untuk memperbesar nilai reflektan air dan dikarenakan Badan air memiliki daya serap lebih kuat pada band SWIR. Deteksi banjir menggunakan indeks air dapat bercampur dengan genangan yang tidak berasal dari banjir (penampungan air selama penanaman padi).

\section{Daftar Pustaka}

[1] A. Rosyidie, Banjir: Fakta dan Dampaknya, serta Pengaruh dari Perubahan Guna Lahan, Jurnal Perencanaan Wilayah dan Kota. 2013, 24: 241-249.

[2] K. K Kurniadi, I. P. A Bayupati, and I. D. N. Nurweda Putra, Aplikasi Penghitungan Gross Primary Production dari Data Penginderaan Jauh, Lontar Komputer. 2016, 7(1): 31-39.

[3] I. P. W. S Putra, I. K. G Darma Putra, et. al, Applicatoin of Mangrove Forest Coverage Detection in Ngurah Rai Grand Forest Park Using NDWI Transformation Method, Journal of Theoretical and Applied Information Technology. 2015, 80(3): 521-527.

[4] I. K. Ariana, R. S. Hartati, N. K. Ayu Wirdiani, et. al, Color Image Segmentation using Kohonen Self-Organizing Map (SOM), International Journal of Engineering and Technology (IJET). 2016, 6(2): 865-871.

[5] Sitta Rahayu, I. N. Piarsa, et. al, Sistem Informasi Geografis Pemetaan Daerah Aliran Sungi Berbasis Web, Lontar Komputer. 2016, 7(2): 71-83.

[6] I.B.K. Putra Susila, I.D. N. Nurweda Putra, et. al, Rancang Bangun Aplikasi Analisa Pola Hujan Penyebab Banjir Di Jakarta, Lontar Komputer. 2017, 5(3): 151-161.

[7] Suwarsono, J. T. Nugroho, Wiweka, Identification of Inundated Area Using Normalized Difference Water Index (NDWI) on Lowland Region of Java Island, International Journal of Remote Sensing and Earth Sciences. 2013, 10(2): 115-118.

[8] Yun Du, Yihang Zhang, et. al, Water Bodies' Mapping from Sentinel-2 Imagery with Modified Normalized Difference Water Index at 10-m Spatial Resolution Produced by Sharpening the SWIR Band, Remote Sensing. 2016, 8(4): 1-19.

[9] A. A Memon, S. Muhamma, et. al, Flood Monitoring and Damage Assessment Using Water Indices: A Case Study of Pakistan Flood-2012, The Egyptian Journal of Remote Sensing and Space Sciences. 2015, 18: 99-106

[10] G. Sitanggang, Kajian Pemanfaatan Satelit Masa Depan: Sistem Penginderaan Jauh Satelit LDCM (Landsat-8), Berita Dirgantara. 2010, 11(2): 47-58.

[11] Lili Somantri, Pemanfaatan Teknik Penginderaan Jauh untuk Mengidentifikasi Kerentanan dan Resiko Banjir, Jurnal Gea. 2008, 8(2): 1-6.

[12] G. Sitanggang, Kajian Pemanfaatan Satelit Masa Depan: Sistem Penginderaan Jauh Satelit LDCM (Landsat-8), Berita Dirgantara. 2010, 11(2): 47-58.

[13] L. Kristianingsih, A. P. Wijaya, et al, Analisis Pengaruh Koreksi Atmosfer Terhadap Estimasi Kandungan Klorofil-A Menggunakan Citra Landsat 8, Jurnal Geodesip Undip. 2016, Vol. 5(4): 56-64.

[14] K. Rokni, A. Ahmad, et al, Water Feature Extraction and Change Detection Using 
MERPATI VOL. 7, NO. 1 APRIL 2019

ISSN: 2252-3006

Multitemporal Landsat Imagery, Remote Sensing. 2016 6: 4173-4189. 